\title{
THE INFLUENCE OF THERAPY DO'A IN ISLAM TO THE COOPERATIVE CLIENTS SKIZOFRENIA COOPERATIVE WATER PATHWAY IN PUBLIC HEALTH CENTER KARANGANYAR, GANDUSARI TRENGGALEK, EAST JAVA
}

\author{
Sunaryo \\ Puskesmas Karanganyar Trenggalek \\ Corresponding author : sunaryopuskesmaskaranganyar@gmail.com
}

\begin{abstract}
Background: Coping mechanism is a process whereby individuals try to handle and master stressful situations that suppress the consequences of the problems it faces, it is very necessary in patients with psychiatric.

Purpose : The purpose of this study was to analyze the effect of pre- and post-intervention therapy on cooperative mechanisms of cooperative schizophrenia

Methods : The research design used in this research is experimental pre with one group pretest and posttest approach where the mechanism of client cloning before and after Schizophrenia is given intervention in the form of prayer therapy. The analysis used is descriptive where the data is taken directly on each respondent, the score obtained from each respondent will be adjusted with the standard assessment, while testing the hypothesis using $\mathrm{t}$ test Dependent analysis.

Result : Based on the result of statistical test, the mechanism of cooperative schizophrenia client cooperate in outpatient care in health center of Puskesmas Karanganyar Gandusari District Trenggalek mean difference of therapy of prayer in Islam before therapy and after therapy is 0,400 with standard deviation 0,503 . Beside that got value $p$ value $=0,002$.

Conclusion :The results of this study indicate there is a significant difference between before prayer therapy and after therapy do'a to coping mechanism of client of schizophrenia.
\end{abstract}

Keywords : Prayer therapy, Coping, Skizofrenia

Received February 03, 2018; Revised February 24, 2018; Accepted March 10, 2018

How to Cite: Sunaryo. (2018). The Influence Of Therapy Do'a In Islam To The Cooperative Clients Skizofrenia Cooperative Water Pathway In Public Health Center Karanganyar, Gandusari Trenggalek, East Java. Journal Of Nursing Practice. 1(2). 8-15. 


\section{BACKGROUND}

Schizophrenia is a disorder generally characterized by fundamental and distinctive distortions in the process of thinking and perception, unfit and dull affects. This disorder involves the most basic functions that make a normal individual feel the feelings of individuality, such as the most intimate thoughts, feelings, and behaviors often seem to be known to others and delusions may be explained, as the effects of natural forces and supra natural that affect the way of thinking and behaving that is often strange. The magnitude of mental health problems from household health surveys conducted by the Indonesian Ministry of Health Research and Development (MOHRI) with susenas-BPS (Badan Pusat Statistik) sample of 65,664 households found the prevalence of mental disorders 140/1000 household members and the prevalence of schizophrenia reached 3/1000 population. Trenggalek regency in 2011, there were 1599 cases of mental disorders. Visits to the Karanganyar community health center in 2011 there were 127 new cases and 379 old cases, most (70\%) were serious mental disorders.

Preliminary studies of dipoli mental health of the 11 patients observed had never been given prayer therapy. Coping mechanism is a process whereby individuals try to handle and master stressful situations that suppress the effects of problems faced by how to make changes in cognitive and behavior in order to obtain a sense of security in itself. The two coping strategies employed by individuals are solfing focused coping problems that actively seek solutions to problems or situations that cause stress and emotion focused coping where the individual involves attempts to regulate his emotions in order to adapt to the impact that a conditions or stressful situations.

Spiritual spiritual therapy is also called holistic therapy meaning physical, psychological, psychosocial and spiritual therapy. Through the workshop of religion and psychiatric model of partnership (1993), advocated adding religious therapy in addition to psychic and medical therapy (setiyo, 2007). Confidence (self confidence) and hope of healing (optimism) are two things that are essential for the cure of disease in addition to medication and medical treatment. One of the religious actions is to pray. that is to say a plea to God to obtain a desired desire so as to affect the psychological changes and somatic changes. The purpose of this study is to analyze the influence of prayer therapy before and after intervention to cooperative mechanism of cooperative schizophrenia 


\section{OBJECTIVE}

The purpose of this study was to analyze the effect of pre- and post-intervention therapy on cooperative mechanisms of cooperative schizophrenia

\section{METHODS}

The research design used in this research is experimental pre with one group pretest and posttest approach where the mechanism of client cloning before and after Schizophrenia is given intervention in the form of prayer therapy. The population of this study are all schizophrenia clients registered in Poly Soul Puskesmas Karanganyar Gandusari Trenggalek as many as 186 people, with a large sample of 20 respondents. Sampling using consecutive sampling is selecting samples that meet the study criteria until a certain time so that the number of samples are met.

The research was conducted in health polyclinic puskesmas Karanganyar Gandusari Trenggalek for 1 month since 17th of March until 17th April 2012. The analysis used is descriptive where the data is taken directly on each respondent, the score obtained from each respondent will be adjusted with the standard of assessment. While testing the hypothesis using $t$ test dependent analysis.

\section{RESULTS}

The working area of puskesmas karanganyar is $17.83 \mathrm{~km}^{2}$, divided into 5 villages namely sukorame, krandegan, melis, karanganyar, and widoro. Population density is 1.009 inhabitants $/ \mathrm{km}^{2}$. Puskesmas Karanganyar is located at RT 06 RW 02 Karanganyar Village, Gandusari District. The human resources of the health personnel at the community health center consist of two doctors, 1 dentist, 2 nurses, 13 nurses, midwives 7 people, 1 dental nurse, 1 pharmacist assistant, 1 sanitarian, 1 person nutritionist, administrative personnel 9 people. Descriptive analysis results on variables Prior to prayer therapy it was found that most (65\%) or 13 of 20 respondents stated their coping mechanism was effective.

Table 1. Characteristics Before prayer therapy in Schizophrenic Patients

\begin{tabular}{lcc}
\hline \multicolumn{1}{c}{ Before Therapy } & F & \% \\
\hline Efective Coping & 7 & 35 \\
Inefective Coping & 13 & 65 \\
Jumlah & $\mathbf{2 0}$ & $\mathbf{1 0 0}$ \\
\hline
\end{tabular}


Whereas after prayer therapy Based on the distribution of characteristics after prayer therapy in schizophrenic patients showed most (75\%).

Table 2. Characteristics After therapy of prayer in Schizophrenic Patients

\begin{tabular}{lcc}
\hline \multicolumn{1}{c}{ After therapy } & F & \% \\
\hline Efective Coping & 15 & 75 \\
Inefective Coping & 5 & 25 \\
\multicolumn{1}{c}{ Jumlah } & $\mathbf{2 0}$ & $\mathbf{1 0 0}$ \\
\hline
\end{tabular}

The dependent $t$ test is often used in experimental data analysis. Besides, the dependent $t$ test is often called t pair / related test or pair. This is in accordance with the variables in this study, ie the two dependent variables in which the sample groups are compared have the same subject.

Table 3. The average therapy of prayer in the patients with schizophrenia

\begin{tabular}{lcccc}
\hline No & Variabel & Mean & SD & SE \\
\hline 1. & Before Therapy & 1,650 & 0,489 & 0,109 \\
2. & After Therapy & 1,250 & 0.444 & 0,099 \\
\hline
\end{tabular}

The average of prayer therapy in Islam in prayer therapy in Islam toward coping mechanisms of cooperative schizophrenic clients in outpatient care in Puskesmas Karanganyar Gandusari Trenggalek community health center at the time before therapy was 1.65 with a standard deviation of 0.489 . Whereas in the second measurement obtained on average after receiving prayer therapy in Islam mechanism of cooperative schizophrenia client cooperate in outpatient care in health clinic Puskesmas Karanganyar Gandusari Trenggalek 1,250 with standard deviation 0,444 .

To test the proposed hypothesis accepted or rejected, then in this study used in test dependent because both samples are dependent. In addition, because the variables are compared have the same object that is compared cooperative mechanism cooperative schizophrenia between before and after follow prayer therapy. $T$ test result dependent with provisions if $\mathrm{p}$ value $<0,05$ then $\mathrm{H} 0$ is rejected and $\mathrm{H} 1$ accepted. Conversely, if $\mathrm{p}$ value $>0,05$ then $\mathrm{HO}$ is accepted and $\mathrm{H} 1$ is rejected. 
Table 4. Test statistics of prayer therapy in Schizophrenic patients

\begin{tabular}{llccc}
\hline No $\quad$ Variabel & Mean & SD & SE & P Value \\
\hline $\begin{array}{l}\text { 1. Before Therapy } \\
\text { 2. After Therapy }\end{array}$ & 0,400 & 0,503 & 0,112 & 0,002 \\
\hline
\end{tabular}

Based on the result of statistical test, the mechanism of cooperative schizophrenia client cooperate in outpatient care in health center of Puskesmas Karanganyar Gandusari District Trenggalek mean difference of therapy of prayer in Islam before therapy and after therapy is 0,400 with standard deviation 0,503 . Beside that got value $p$ value $=0,002$, hence can be concluded that there is significant difference between before therapy of prayer and after therapy do'a to mechanism of cooperative client cooperative schizophrenic cloning in health polis health Puskesmas Karanganyar Gandusari Trenggalek.

\section{DISCUSSION}

Seeing the results of descriptive analysis before the do'a therapy describes most schizophrenic clients in the mental health pole Karanganyar Puskesmas Gandusari Trenggalek less have the ability to handle and master stressful situations that suppress the consequences of the problems it faces. Naturally conscious or unconscious individuals have actually used coping strategies in the face of stress. Coping strategies are the way in which to change the environment or situation to solve a problem that is being felt or faced. Effective coping produces persistent adaptations that are new habits and improvements from the old situation, whereas ineffective coping ends with maladeprojects that are deviating from normative desires and can harm themselves or others or the environment. Based on the description it can be assumed that a schizophrenic client whose coping mechanism is ineffective has an inability: to pour out the heart of the problem, to seek information about the problem at hand, to connect problems faced with a spiritual approach, to relax, to discuss with others about alternative problem solving.

While descriptive analysis after prayer therapy on client skizofreniamenggambarkan most clients skizofreniadi poli mental health Puskesmas Karanganyar Gandusari Trenggalek after doing prayer therapy in Islam has the ability to handle and master stressful situations that suppress the consequences of the problems it faces. Coping mechanism is a process whereby individuals try to handle and master stressful situations that suppress the consequences of 
problems faced by how to make changes in cognitive and behavior in order to obtain a sense of security in itself. In addition, experts classify two coping strategies that can be used by individuals solfing focused coping problem where individuals are actively seeking solutions from problems to eliminate stressful and emotion focused coping situations or situations where the individual involves attempts to regulate his emotions in order to adapt yourself with the impact that will be caused by a stressful condition or situation. From the analysis the researcher assumed that the patient of cooperative schizophrenia outpatient in the health policewomen of Puskesmas Karanganyar Gandusari District of Trenggalek Regency after receiving the therapy do'a have the ability to handle and master stressful situation that suppress the result of the problem that is facing. It is possible that prayer provides an opportunity for individuals to renew confidence and trust in Almighty God in a more formal way.

Based on the result of $t$ test of dependent (paired sample test) it can be concluded there is a significant difference between before the therapy of prayer and after prayer therapy in Islam against coping mechanism of client cooperative schizophrenia outpatient in health polis health Puskesmas Karanganyar Gandusari Trenggalek ( $p$ value $=0.002$ ). Praying that is done solemnly, solemnly, accurately, sincerely and continuously, is thought to foster positive perception and motivation in activating coping, as Rehatta said, that positive emotional response (positive thinking) can avoid stress reactions (Rehatta, 2004 in Sholeh, 2005 ). Prayer is also a positive reinforcement and motivator, so prayer can make the spirit and soul able to defeat everything that has a negative impact on them. Based on the description, the authors assume that the therapy of prayers performed on the patient's cooperative schizophrenia outpatient in the mental health pole Karanganyar Puskesmas Gandusari Trenggalek District has a very big role in determining and encouraging the ability to handle and master stressful situations that suppress the effects of problems that are faced him.

\section{CONCLUSION}

From the results of research ynag researchers have done in the health of mental health center Karanganyar Gandusari Trenggalek regency starting from 17 March to 17 April 2012 can be concluded that: 
1. The coping mechanism of an outpatient schizophrenic client prior to prayer therapy showed that most $(65 \%)$ or 13 of the 20 respondents stated the coping mechanism was ineffective.

2. The coping mechanism of an outpatient schizophrenic client following a prayer therapy showed that most $(75 \%)$ or 15 of 20 respondents stated their coping mechanism was effective.

3. There is a significant difference between before and after prayer therapy on the mechanism of cooperative cooperative schizophrenic coping of outpatients in the mental health pole of Karanganyar Puskesmas Gandusari Trenggalek, as indicated by the dependent $t$ test, that is, the average value of the difference of 0.400 with a standard deviation of 0.503 and a significance value of $0.002(\mathrm{p}<\mathrm{Alpha})$.

\section{REFERENCES}

Agusno,Mahar, (2009) Perjalanan Panjang Skizofrenia,Indoesian Psychiatric Quarterly Jakarta : Yayasan Kesehatan Jiwa Dharmawangsa.

Arikunto,Suharseni (2006 ) Prosedur Penelitian Suatu Pendekatan Praktik, Jakarta : Rineka Cipta

Burdah, Ibnu (2005) Do'a dan Penyembuhan Cara Nabi, Yogyakarta : Mitra Pustaka

Darwis,Yulisar,dkk (2004) Pedoman Pelayanan Kesehatan Jiwa Dasar Di Puskesmas, Jakarta : Depkes RI

Hidayat, A. Aziz Alimul (2007) Riset Keperawatan dan Teknik Penulisan Ilmiah, Surabaya Salemba Medika

Issaes, Ann (2005) Keperawatan Jiwa dan Psikiatrik, Edisi 3, Jakarta, EGC

Keliat, Budiana dkk (2006) Proses Keperawatan Jiwa ,Edisi 2, Jakarta : EGC

Maramis, WF (2005) Catatan Ilmu Kedokteran Jiwa, Surabaya : Airlangga University Press

Rasmun, (2005) Stress, Koping dan Adaptasi, Jakarta : Sagung seto

Ridwanullah, Qosdi, Dzikir Pagi dan Sore beserta Fadhilahnya, 2008, Boyolali, Zaka.

Sangkan, Abu (2006) Pelatihan Sholat Khusyu',Sholat Sebagai Meditasi Tertinggi Dalam Islam, Jakarta : Sholat Centre dan Baitul Ihsan

Sholeh, Muhammmad ( 2007) Terapi Sholat Tahajud Menyembuhkan Beberapa Penyakit, Jakarta : Hikmah Populer

Stuart W Gail, (2007) Buku Saku Keperawatan Jiwa, Edisi 5, Jakarta, EGC 
Thalib, Muhammmad (2005) Dzikir Dan Do'a Sholih, Jakarta : Media Hidayah

Tun K Bustaman, At All, (2003) Leksikon Istilah Kesehatan Jiwa dan Psikiatrik, Jakarta : EGC

Widyastuti, Palupi (2004) Manajemen Stress, Jakarta : EGC

Yosep, Iyus (2009) Keperawatan Jiwa, Bandung : Refika Aditama 